\title{
Comparative interactions of streptozotocin and chlorozotocin with DNA of an insulin-secreting cell line (RINr)
}

\author{
B. T. Mossman ${ }^{1}$, C. M. Ireland ${ }^{1}$, M. Filipak ${ }^{1}$, S. LeDoux ${ }^{2}$ and G. L. Wilson ${ }^{2}$ \\ ${ }^{1}$ Department of Pathology, University of Vermont College of Medicine, Burlington, Vermont and ${ }^{2}$ Department of Anatomy, \\ University of South Alabama, Mobile, Alabama, USA
}

\begin{abstract}
Summary. Both streptozotocin and chlorozotocin, the 2-chloroethyl analogue of streptozotocin, are diabetogenic chemicals in rodents. Although these chemicals are similar structurally, they appear to act on pancreatic B cells via different mechanisms [1,2]. In studies here, damage and repair of DNA after exposure of an insulin-secreting cell line to streptozotocin and chlorozotocin were assessed by nucleoid sedimentation and alkaline elution. Equitoxic concentrations of streptozotocin and chlorozotocin caused significant single-strand breakage of DNA $(p<0.005)$. These lesions were repaired in a time-dependent manner, with most repair completed by 24-h post-exposure to chemicals. Additionally, chlorozotocin caused DNA-DNA and DNA-protein crosslinks in insulinoma cells. When proteinase $\mathrm{K}$ was included in the crosslinking
\end{abstract}

assay, a substantial proportion of the chlorozotocin-associated crosslinks proved to be DNA interstrand in nature. Analysis of the amount of interstrand crosslinking in insulinoma cells after exposure to chlorozotocin for $1 \mathrm{~h}$ showed that formation of interstrand crosslinks was slow. Increasing amounts appeared over a $24-\mathrm{h}$ period. These results suggest that the formation of irreversible DNA interstrand crosslinks may be a critical factor in cytotoxicity and diabetogenicity caused by chlorozotocin.

Key words: Streptozotocin, chlorozotocin, pancreatic B cell, insulinoma, alkaline elation, nucleoid sedimentation, DNA crosslinks, DNA breakage, cytotoxicity, diabetes.
Streptozotocin (SZ) and chlorozotocin (CLZ) are glucose-containing analogues of the $\mathrm{N}$-nitroso compounds, methylnitrosourea (MNU) and chloroethylnitrosourea. Streptozotocin is a well-documented diabetogenic agent in laboratory animals [review, 3] and is selectively toxic to B cells in comparison to pancreatic fibroblasts in vitro [2]. Recent studies by this laboratory have shown that CLZ exhibits a tropism similar to $\mathrm{SZ}$ towards pancreatic B cells in culture [2] and is diabetogenic in hamsters and mice $[1,4]$.

The reason for the specificity of SZ and CLZ for $B$ cells is unclear, although several studies imply that the presence of the glucose moiety is important. For example, SZ-induced diabetogenicity in rodents is ameliorated after administration of 3-0-methylglucose or 2-deoxyglucose, analogues of glucose [5-7]. In addition, the administration of equivalent amounts of SZ in comparison to its non-glucose containing analogue, MNU, results in a 3.8-fold higher accumulation of SZ in insular tissue [3]. Thus, data suggest that the specificity of CLZ for pancreatic B cells also may be related to the presence of glucose in its chemical structure.

The cytotoxic effects of SZ are thought to be related to a depletion of pyridine nucleotides, specifically NAD, in B cells [8-10]. After breakage of DNA, activation of the nuclear enzyme, ADP ribosyltransferase, and enzyme using NAD as a substrate, occurs. Subsequently, reduction of levels of NAD in the B cell is associated with cell death [10]. In support of this hypothesis, breakage of DNA and reduction of NAD caused by SZ in islet cells can be prevented by administration of inhibitors of ADP ribosyltransferase such as nicotinamide and picolinamide [11, 12]. Diabetes also is prevented in animals when inhibitors of ADP ribosyltransferase are administered with $\mathrm{SZ}[1,4,9,13]$.

In comparative studies using SZ and CLZ, no alleviation of diabetogenicity caused by CLZ in hamsters is observed with use of nicotinamide [1]. Moreover, addition of nicotinamide prevents SZ- but not CLZ-induced injury to $\mathrm{B}$ cells in vitro [2]. These studies indicate that the cytotoxic effects of CLZ and SZ may involve different mechanisms. Like SZ, the $\mathrm{N}$-nitroso component of CLZ is capable of spontaneously decomposing under physiological conditions into two reactive products these can be alkylate or carbamoylate nucleophilic sites $[14,15]$. The major alkylating product, chloroethyl carbonium ion, may form chloroethyl adducts with nucleic acids and proteins. These chloroethyl adducts then can act as alkylating agents capable of reacting with a second nucleophilic site by eliminating $\mathrm{Cl}^{-}[16,17]$. As a consequence, covalent crosslinks can occur between complementary strands of DNA and/or between DNA 
and protein. Both types of crosslinks have been detected in other cell types exposed to various chloroethylnitrosoureas using the alkaline elution technique [18, 19].

In light of the above data, we speculated that the toxic effects of CLZ in pancreatic B cells might involve both alkylation of DNA bases at specific sites and the subsequent formation of DNA-interstrand and DNAprotein crosslinks. Since it is difficult to obtain sufficient amounts of DNA from normal pancreatic B cells to allow these quantitative studies, a clonal isolate of a rat insulinoma cell line (RINr clone 38 ) was used. This study investigates the formation of DNA breaks and crosslinking in RINr cells after exposure to either streptozotocin or chlorozotocin.

\section{Materials and methods}

\section{Cell culture}

Insulinoma cells (obtained from Dr. William Chick, University of Massachusetts Medical School, Worcester, MA, USA) were maintained as monolayers in M-199 medium supplemented with mycostatin $(25 \mathrm{U} / \mathrm{ml}), 10 \%$ fetal calf serum (Gibco, Grand Island, NY, USA), gentamycin $(100 \mu \mathrm{g} / \mathrm{ml})$ and glucose $(100 \mathrm{mg} / \mathrm{dl})$. The specific clone (RINr clone 38) used in studies here was selected because it secretes insulin in relatively large amounts. These cells were subcultured by gentle trypsinization twice weekly. For alkaline elution assays, insulinoma cells were split $24 \mathrm{~h}$ prior to each experiment and seeded at a density of $10^{6}$ cells $/ 60 \mathrm{~mm}$ dish in the presence of methy- ${ }^{3} \mathrm{H}$-thymidine $(43 \mathrm{Ci} / \mathrm{mmol} / \mathrm{I}$, Amersham; final concentration $0.2 \mu \mathrm{Ci} / \mathrm{ml} \mathrm{me}-$ dium). Radiolabeled medium was removed and replaced with fresh medium $4 \mathrm{~h}$ prior to each experiment.

\section{Experimental protocol}

Streptozotocin (Sigma Biochemicals, St. Louis, MO, USA) was prepared as $0.1 \mathrm{~mol} / 1$ solution in citrate buffer $(\mathrm{pH} 4.5)$ and diluted in Earle's buffered salt solution before adding to cells. This procedure yielded a solution with a $\mathrm{pH}$ within the range of 6.8-7.0. Chlorozotocin (a gift from Dr. Robert Engle, National Cancer Institute, Bethes$\mathrm{da}, \mathrm{MD}$, USA) was dissolved in dimethyl sulfoxide and also diluted in salt solution. The final medium was adjusted to give a concentration of $1 \%(\mathrm{v} / \mathrm{v})$ dimethyl sulfoxide or citrate. Cells were incubated with drugs at $37^{\circ} \mathrm{C}$ for $1 \mathrm{~h}$ before preparation for nucleoid sedimentation, alkaline elution or re-incubation in drug-free medium for various periods. Control dishes received mock treatment with appropriately diluted citrate buffer or DMSO. Concentrations of drugs selected for experiments were those producing a statistically significant decrease in immunologically reactive insulin release during a 48 - $h$ period (Table 1).

For alkaline elution studies, cells receiving $\mathrm{x}$-irradiation were harvested using a rubber policeman and resuspended in $1 \mathrm{ml}$ rinsing buffer $\left(75 \mathrm{mmol} / \mathrm{I} \mathrm{NaCl}, 24 \mathrm{mmol} / 1 \mathrm{Na}_{2}\right.$ EDTA, pH 7.0). Cells were placed on ice immediately and were exposed to $300 \mathrm{rad} X$-rays at a dose rate of $50.9 \mathrm{rad} / \mathrm{min}\left(1.2 \mathrm{MeV}^{60} \mathrm{Co}\right.$ source, Theratron Jr. Atomic Energy of Canada Ltd., Toronto).

\section{Nucleoid assay}

Nucleoid assays were performed as described by LeDoux and Wilson [20]. Gradients of $15-30 \%$ sucrose, $1.95 \mathrm{~mol} / 1 \mathrm{NaCl}, 0.01 \mathrm{~mol} / 1$ Tris, and $0.001 \mathrm{~mol} / 1$ EDTA (pH 8.0 ) were prepared in $4.6 \mathrm{ml}$ polyallomer tubes using a Buchler density gradient maker. A $0.5 \mathrm{ml}$ aliquot of $60 \%$ sucrose was used as a cushion. Lysis solution ( $150 \mu \mathrm{l}$ containing $2.6 \mathrm{~mol} / 1 \mathrm{NaCl}, 0.133 \mathrm{~mol} / 1 \mathrm{EDTA}, 2.6 \mathrm{~mol} / \mathrm{l}$ Tris, and $0.345 \%$ Triton $\mathrm{X}-100$ ) was then layered gently onto the gradients. Following trypsinization, the cells were resuspended in $50 \mu \mathrm{l}$ of ice-cold $0.01 \mathrm{~mol} / 1 \mathrm{phos}-$ phate buffered saline $(0.01 \mathrm{~mol} / 1$ monobasic sodium phosphate,
$0.01 \mathrm{~mol} / 1$ dibasic sodium phosphate in $0.875 \mathrm{~mol} / 1 \mathrm{NaCl}$ solution at pH 7.4). Subsequently, this suspension was layered gently on top of the lysing solution. After a $30 \mathrm{~min}$ lysis period in the dark, the gradients were centrifuged for $30 \mathrm{~min}$ at $25,000 \mathrm{rpm}$ at $20^{\circ} \mathrm{C}$ using a Sw55Ti rotor in an ultracentrifuge (Beckman Model L-2, Palo Alto, CA, USA). Gradients were pumped through a continuous flow cell in an (ISCO Model UA5, Lincoln, NE, USA) absorbance monitor, and absorbance was monitored at $254 \mathrm{~nm}$. The migration ratio was calculated as the distance migrated by damaged nucleoids relative to the distance migrated by undamaged control nucleoids.

\section{Alkaline elution}

Alkaline elution assays were performed as described by Ireland et al. [21]. Cells were harvested into $1 \mathrm{ml}$ rinsing buffer and applied to $2 \mu \mathrm{m}$ pore size PVC filters (Millipore, type BSWP) in $2.5 \mathrm{ml}$ lysing solution ( $2 \mathrm{~mol} / 1 \mathrm{NaCl}, 20 \mathrm{mmol} / 1 \mathrm{Na}_{2}$ EDTA, $0.2 \%$ sarkosyl, pH 9.0). A $7.5 \mathrm{ml}$ lysing solution then was pumped through the filters followed by $10 \mathrm{ml}$ of EDTA solution ( $20 \mathrm{mmol} / 1 \mathrm{Na}_{2}$ EDTA, pH 9.0). The DNA was then eluted with tetrapropylammonium hydroxide solution containing $20 \mathrm{mmol} / 1 \mathrm{H}_{4}$ EDTA, pH 12.15 , at a flow rate of $2 \mathrm{ml} / \mathrm{h}$. The elution procedure was carried out in the dark at a constant temperature of $27^{\circ} \mathrm{C}$. In experiments using proteinase $\mathrm{K}$, a concentration of $100 \mu \mathrm{g} / \mathrm{ml}$ was present in the lysing and EDTA solutions. Hourly fractions were collected for $16 \mathrm{~h}$ and neutralized with $50 \mu \mathrm{l}$ glacial acetic acid. Radioactivity was determined by counting in $10 \mathrm{ml}$ Instagel (Packard, Downers Grove, IL, USA). At the end of elution, filters were removed and heated at $80^{\circ} \mathrm{C}$ for $30 \mathrm{~min}$ with $5 \mathrm{ml} \mathrm{IN} \mathrm{HCl}$. They then were cooled and incubated for $30 \mathrm{~min}$ with $0.5 \mathrm{ml}$ of $1 \mathrm{~mol} / 1$ $\mathrm{NaOH}$. Filters were neutralized with $10 \mu \mathrm{l}$ glacial acetic acid and counted in $10 \mathrm{ml}$ Instagel. Results are expressed as the fraction of radioactivity remaining on the filter at given elution times. Apparent interstrand crosslink frequency in rad equivalents was determined using the formula of Ewig and Kohn [19]:

$\left(1-r_{0}\right) /(1-r)-1 \times 300 \mathrm{R}$

where $r_{0}$ and $r$ are the fractions of DNA remaining on the filter after $12 \mathrm{~h}$ of alkaline elution for control and drug-exposed cells, respectively.

\section{Statistical analysis}

All data from experiments described above are expressed as the mean \pm standard error for each group. Data were compared using the Student's t-test for unpaired samples. A value of $p \leqslant 0.005$ was considered significant.

\section{Results}

\section{Cytotoxicity of chemicals}

Cytotoxicity studies were performed using release of immunologically reactive insulin as a measure of cellular function. RINr cultures were exposed to log doses of $\mathrm{SZ}$ and CLZ ranging from $10^{-2}-10^{-5} \mathrm{~mol} / 1$. The release of immunologically reactive insulin after exposure of cells to various concentrations of SZ and CLZ is shown in Table 1. Whereas slight toxicity was observed at $48 \mathrm{~h}$ with use of SZ at $10^{-2} \mathrm{~mol} / \mathrm{l}, \mathrm{CLZ}$ was more potent. Toxicity of $\mathrm{RINr}$ cells was noted at concentrations of CLZ as low as $10^{-5} \mathrm{~mol} / \mathrm{l}$.

\section{Nucleoid assays}

Changes in nucleoid sedimentation were used to assess DNA damage induced by either CLZ or SZ. Nucleoids are structures which result when cells are lysed in the presence of nonionic detergent and high salt concentrations. They resemble nuclei and contain all the nuclear 
DNA and some of the RNA, but are essentially depleted of protein. As nicks are made in supercoiled DNA, a more relaxed and open structure results in a decreased rate of sedimentation of the nucleoids. Values are ex-

Table 1. The effects of streptozotocin (SZ) and chlorozotocin (CLZ) on immunologically reactive insulin release from insulinoma cells

\begin{tabular}{lll}
\hline & \multicolumn{2}{l}{$\mathrm{mU}$ Insulin released/culture } \\
\cline { 2 - 3 } Incubation conditions & $\mathrm{SZ}$ & $\mathrm{CLZ}$ \\
\hline 48 h Pre-treatment & $0.9 \pm 0.02$ & $1.7 \pm 0.04$ \\
Control & & \\
Concentration & $0.9 \pm 0.02$ & - \\
$10^{-2} \mathrm{mmol} / 1$ & $0.9 \pm 0.02$ & $1.8 \pm 0.00$ \\
$10^{-3} \mathrm{mmol} / 1$ & $1.0 \pm 0.02$ & $1.7 \pm 0.02$ \\
$10^{-4} \mathrm{mmol} / 1$ & - & $1.7 \pm 0.03$ \\
$10^{-5} \mathrm{mmol} / 1$ & & \\
$48 \mathrm{~h} \mathrm{Post-treatment}$ & $6 \pm 0.3$ & $3.1 \pm 0.2$ \\
Control & $4 \pm 0.5^{*}$ & - \\
Concentration & $8 \pm 0.5$ & $0.4 \pm 0.03^{\mathrm{a}}$ \\
$10^{-2} \mathrm{mmol} / 1$ & $9 \pm 0.4$ & $0.7 \pm 0.02^{\mathrm{a}}$ \\
$10^{-3} \mathrm{mmol} / 1$ & - & $1.9 \pm 0.20^{\mathrm{a}}$ \\
$10^{-4} \mathrm{mmol} / 1$ & & \\
$10^{-5} \mathrm{mmol} / 1$ & &
\end{tabular}

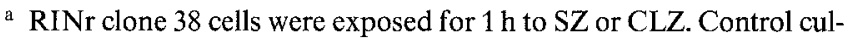
tures were exposed to HBSS containing $1 \%$ citrate phosphate buffer (pH 4.5 ) or 1\% DMSO respectively. Culture medium was collected from individual wells before addition of chemicals (pre-treatment group) and at $48 \mathrm{~h}$ thereafter. Results are expressed as mU (mean \pm SEM) of IRI released in each culture dish ( $n=6$ per group). Experiments were performed in duplicate. ${ }^{a} \mathrm{~A}$ value of $p<0.005$ as determined by the Student's t-test for unpaired samples was considered statistically significant pressed as migration ratios calculated by the distance migrated by damaged nucleoids relative to the distance migrated by undamaged control nucleoids. In studies here, the rate of sedimentation of nucleoids decreased as the concentration of $\mathrm{SZ}$ increased from $10^{-4}-10^{-2} \mathrm{~mol} / 1$ (Fig. 1 A). Concentrations of SZ less than or equal to $10^{-4} \mathrm{~mol} / 1$ did not affect sedimentation velocity significantly, whereas CLZ at $10^{-4} \mathrm{~mol} / 1$ caused a significant decrease $(p<0.005)$ in the migration ratio (Fig. 1 B).

Since both compounds appear to cause damage to DNA, the repair of DNA also was of interest. The ability of RINr cells to repair the nicks and regain the supercoiled configuration after exposure to $\mathrm{SZ}$ is shown in Fig. 2A. As early as $7 \mathrm{~h}$ after exposure to $10^{-3} \mathrm{~mol} / 1 \mathrm{SZ}$, the migration of nucleoids was no longer significantly different from undamaged controls. In contrast, repair of lesions caused by $10^{-3} \mathrm{~mol} / 1 \mathrm{CLZ}$ was slower, as demonstrated by a migration ratio at $14 \mathrm{~h}$ that remained significantly different $(p<0.005)$ from that of control nucleoids (Fig. 2 B).

\section{Total DNA crosslinking}

The technique of alkaline elution allows an estimation of the fragmentation of high molecular weight DNA by measurement of the rate at which DNA elutes in alkaline solution from PVC filters [22]. The elution of DNA is affected by both DNA interstrand crosslinking and DNA-protein crosslinks [23]. In crosslink assays here,

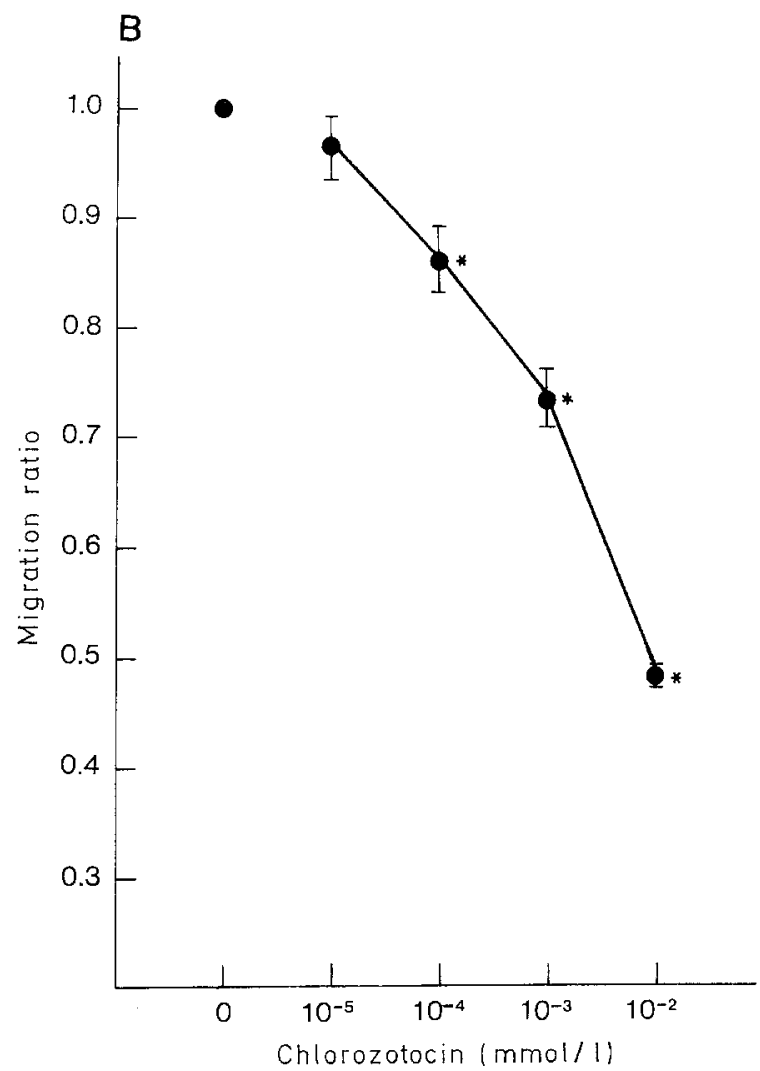

Fig. 1 A and B. Changes in nucleoid sedimentation after a 1-h exposure of insulinoma cells to A SZ or B CLZ. Values are expressed as migration ratios calculated by the distance migrated by damaged nucleoids relative to the distance migrated by nucleoids from control (untreated cells) (Mean \pm SEM of 4 determinations per point). ${ }^{*}=p<0.005$ 

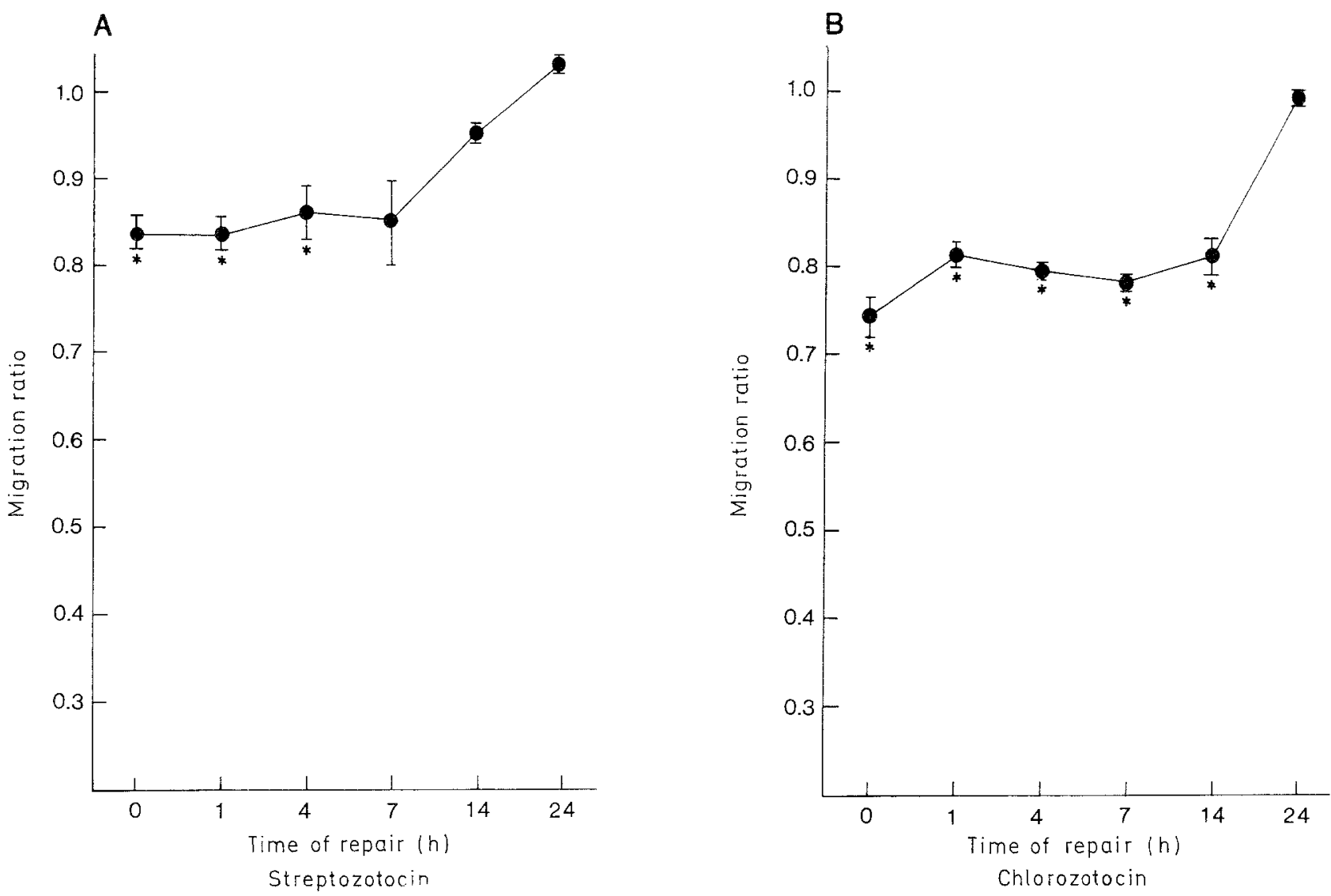

Fig. $2 \mathrm{~A}$ and B. Changes in nucleoid sedimentation at various periods of time after a 1-h exposure of insulinoma cells to A SZ or B CLZ. Values are expressed as migration ratios calculated by the distance migrated by damaged nucleoids relative to the distance migrated by nucleoids from control (untreated cells) (Mean \pm SEM of 4 determinations per point). ${ }^{*} p<0.005$

cells were subjected to $300 \mathrm{R}$ of $\mathrm{X}$-rays at $0^{\circ} \mathrm{C}$ to introduce random single-strand breakage of DNA. The resulting single-strand population of DNA fragments in control cells eluted with first order kinetics. After exposure to SZ, the DNA of insulinoma cells eluted even more quickly than that of control X-irradiated cells, indicating an additive effect between the single strand breaks in DNA caused by SZ damage and $\mathrm{x}$-irradiation (Fig. 3A). No evidence of crosslinking was observed. Following exposure of insulinoma cells to CLZ, however, the elution of $x$-irradiated DNA was slower than that observed in control x-irradiated cells. Data in Figure $3 \mathrm{~A}$ were obtained using $\mathrm{RINr}$ cells exposed for $1 \mathrm{~h}$ to $\mathrm{SZ}$ or CLZ and allowing a $24 \mathrm{~h}$ post-incubation period in the absence of drugs, although similar profiles were obtained after various post-incubation periods. Under these conditions, the crosslinking effect of CLZ could be due to both DNA-protein and DNA-interstrand crosslinks.

\section{DNA interstrand crosslinking}

The effect of DNA-protein crosslinking on alkaline elution can be eliminated with the use of proteinase K. Any remaining decrease in the elution of treated irradiated cells compared to control irradiated cells then can be attributed to DNA interstrand crosslinking [23]. Fig- ure $3 \mathrm{~B}$ shows the elution of DNA from RINr cells exposed to $S Z$ or CLZ and eluted in the presence of proteinase $\mathrm{K}$. In non-irradiated cells, SZ caused a significant increase in elution rate, presumably due to single strand breaks induced by alkylation of SZ to DNA, but caused no evidence of crosslinking. Exposure of cells to CLZ increased the elution rate of DNA slightly in non-irradiated cells, an observation which agrees with the finding that CLZ induces single-strand breaks in DNA as measured by the nucleoid assay. When the crosslink assay was performed after exposure of cells to $\mathrm{CLZ}$ in the presence of proteinase $\mathrm{K}$, a marked retardation of the elution rate of DNA was seen in comparison to that observed in control irradiated cells. These data indicate the presence of DNA interstrand crosslinks caused by CLZ.

The rate of formation of CLZ-induced DNA interstrand crosslinks also was examined (Fig. 4). At various periods after exposure to $10^{-3} \mathrm{~mol} / 1 \mathrm{CLZ}, \mathrm{RINr}$ cells were subjected to $\mathrm{X}$-irradiation and alkaline elution in the presence or absence of proteinase $\mathrm{K}$. While the total apparent crosslinking observed in RINr cells did not vary greatly with the post-incubation period, the level of interstrand crosslinking increased markedly between 6 and $24 \mathrm{~h}$ to levels of $40-50 \mathrm{rad}$ equivalents. After $48 \mathrm{~h}$ post-incubation, marked necrosis and visible sloughing of the cell layer had occurred. Thus, further measurements were precluded. 

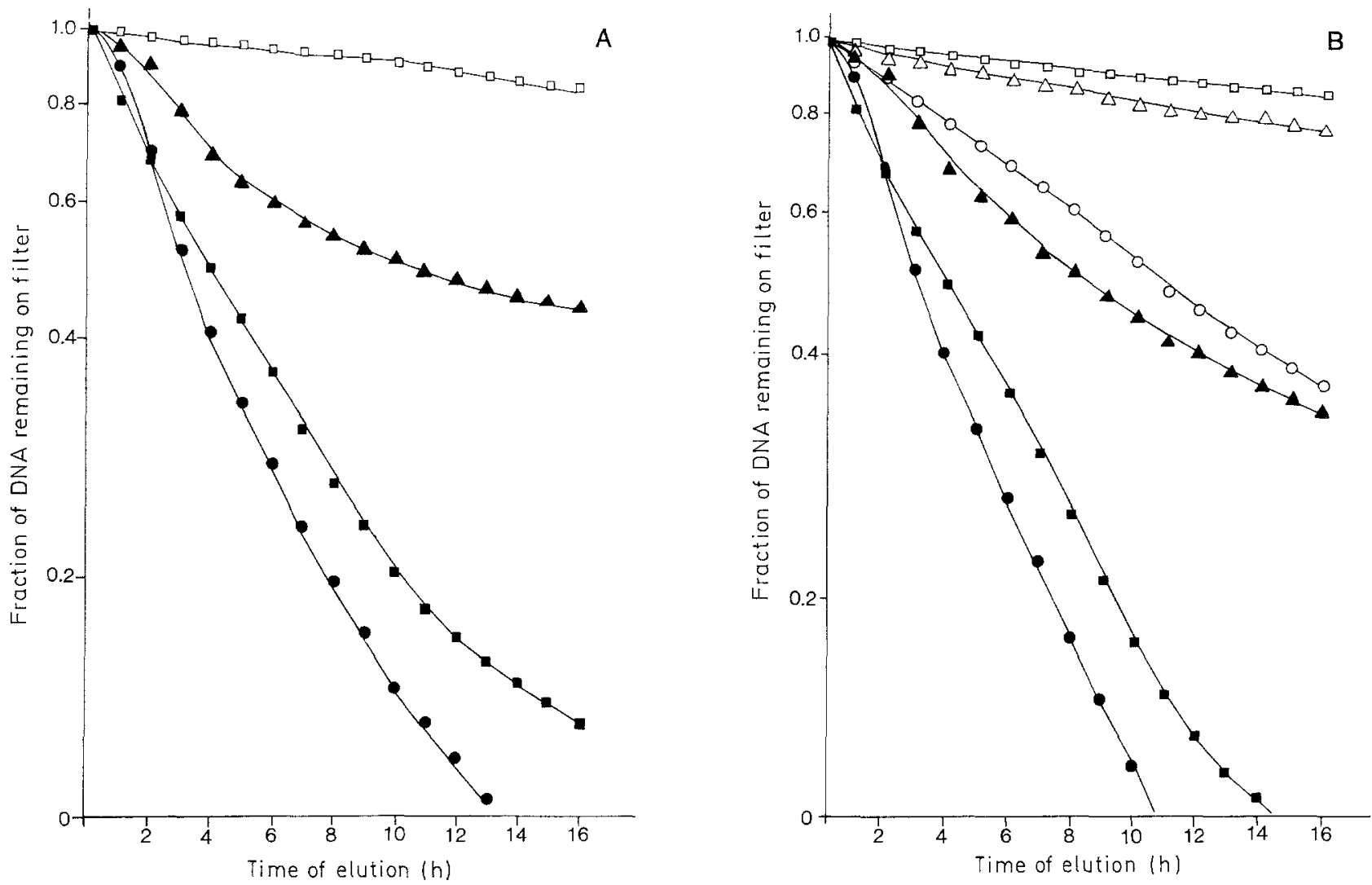

Fig. 3A and B. Results of alkaline elution studies after exposure of insulinoma cells to CLZ $\left(10^{-3} \mathrm{mmol} / 1\right)$ or SZ $\left(10^{-2} \mathrm{mmol} / \mathrm{l}\right)$. A Without addition of proteinase $\mathrm{K}$. Cells were exposed to drugs for $1 \mathrm{~h}$ and maintained in the absence of drugs for $24 \mathrm{~h}$. $\square=$ untreated (control) cells without exposure to X-rays. All other groups were exposed to $300 \mathrm{R}$ at $0^{\circ} \mathrm{C}$. $\mathbf{\square}=$ no drugs; $\Delta=\mathrm{CLZ}$ at $10^{-3} \mathrm{mmol} / 1 ; 0=\mathrm{SZ}$ at $10^{-2} \mathrm{mmol} / 1$. B With addition of proteinase $\mathrm{K}$. Open symbols $=$ no X-ray exposure; filled symbols $=$ exposure to $300 \mathrm{R}$ at $0^{\circ} \mathrm{C} ; \square$ and $\boldsymbol{\nabla}=\mathrm{no}$ drug; $\triangle$ and $\Delta=\mathrm{CLZ}$ at $10^{-3} \mathrm{mmol} / 1 ; O$ and $=\mathrm{SZ}$ at $10^{-2} \mathrm{mmol} / 1$

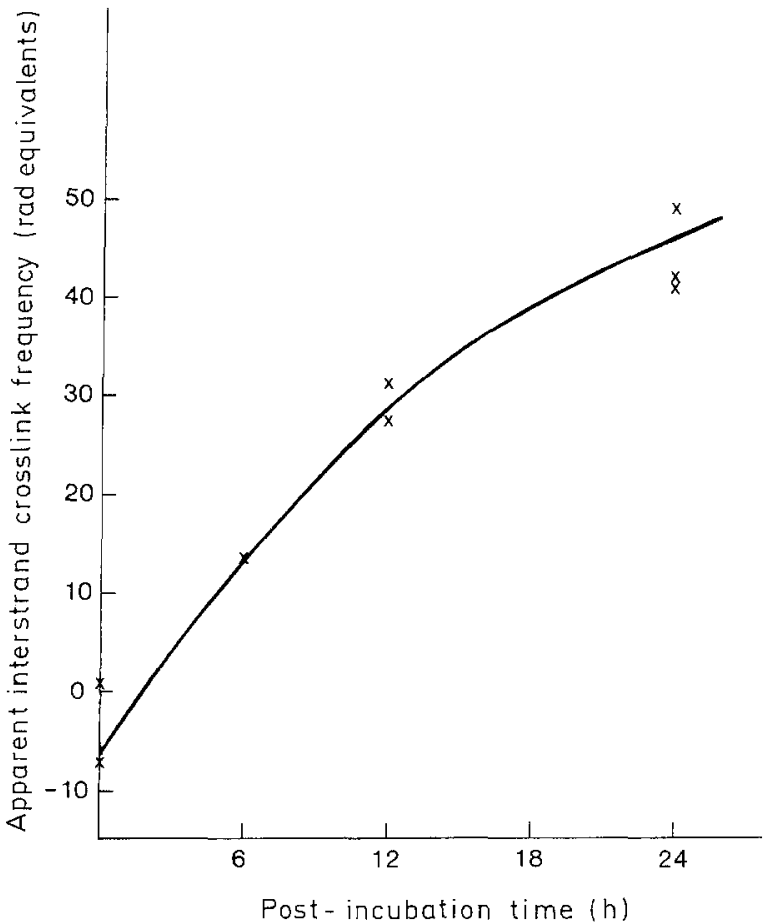

Fig.4. DNA interstrand crosslinking at various time periods after exposure of insulinoma cells for $1 \mathrm{~h}$ to $\operatorname{CLZ}\left(10^{-3} \mathrm{mmol} / \mathrm{l}\right)$. Apparent crosslink frequency was calculated as described in $[19]:\left(\sqrt{\left(1-r_{0}(1-r)\right.}\right.$ $-1 \times 300 \mathrm{R}$, where $r_{0}$ and $r$ are the fractions of DNA remaining on the filter

\section{Discussion}

In comparative studies with SZ, the mechanism of action of CLZ, a diabetogenic and cancer chemotherapeutic agent [24], was explored using quantitation of DNA strand breaks and interstrand crosslinks in a B cell-derived rat insulinoma cell line. Release of immunologically reactive insulin from RINr cells revealed that these cells were sensitive to both drugs, although CLZ was more toxic than SZ at identical concentrations.

As shown in nucleoid assays, SZ, and especially CLZ, alkylate the DNA of RINr cells. These findings correlate well with the relative cytotoxicity of drugs as measured here by inhibition of the release of immunologically reative insulin. After examining the nucleoid sedimentation at varying time intervals following exposure to $10^{-3} \mathrm{~mol} / 1 \mathrm{CLZ}$ or $10^{-2} \mathrm{~mol} / 1 \mathrm{SZ}$, it becomes evident that the nicks are repaired and the DNA is supercoiled again by $24 \mathrm{~h}$. However, repair in cells exposed to CLZ was slower than that observed in cells exposed to SZ. While data here indicated that the majority of DNA lesions are repaired rapidly by the B cell, specific adducts, like $\mathrm{O}^{6}$-methyl or -ethyl guanine, might not be repaired as readily by this cell type. Thus, additional experiments to determine the nature and extent of the remaining adducts are warranted. Work by others 
shows that methylating carcinogens (SZ, MNU) cause a greater overall extent of DNA alkylation but a lower proportion of $\mathrm{O}$-alkylated DNA bases than ethylating or chloroethylating agents at equimolar concentrations [25].

When RINr cells were examined to determine crosslinking by SZ, no crosslinking was observed. Exposure to CLZ, however, caused significant amounts of total DNA crosslinking. Under these conditions, a major proportion of the crosslinks was due to CLZ-mediated covalent binding between DNA strands. The formation of these DNA interstrand crosslinks was slow, an observation consistent with the time course of formation of DNA interstrand crosslinks by CLZ in other mammalian cells [19]. In these situations, the crosslinking reaction follows biphasic kinetics with a rapid initial but slower second alkylation phase generating a bifunctional adduct between DNA strands. To enable formation of interstrand crosslinks, the monoadduct must persist in the DNA for a sufficient period of time for the second reaction to occur. Thus, the repair of monoadducts is an important factor in the extent of crosslink formation. Repair of adducts such as $\mathrm{O}^{6}$-ethylguanine does not require excision repair but depends on the transfer of the alkylation species onto a specific enzyme $\left(\mathrm{O}^{6}\right.$-methyltransferase) [26]. Although it remains to be determined, the degree of interstrand crosslinks produced by CLZ in RINr cells suggests a defect in levels or activity of this enzyme in these cell types.

This study shows that both CLZ and SZ alkylate the DNA of insulinoma cells. Additionally, CLZ induces the formation of both DNA-protein and DNA interstrand crosslinks. While formation of interstrand crosslinks may not be the only factor governing the enhanced cytotoxicity of CLZ in RINr cells, it is reasonable to speculate that these crosslinks are important in enhanced cellular damage by the compound.

Acknowledgements. The authors thank Ms. J.Carrassi, Ms. C. Laplume and Ms. J.Rivers for preparation of the manuscript and Ms. R. Gilbert for graphics. This work was supported by NIH grants ES02113, and ES03066, and ES03456. G. L. Wilson is the recipient of a Research Career Development Award from the NIH (ES00150).

\section{References}

1. Mossman BT, Wilson GL, Craighead JE (1985) A diabetogenic analogue of streptozocin with dissimilar mechanisms of action on pancreatic beta cells. Diabetes 34: 602-607

2. Wilson GL, Mossman BT, Craighead JE (1983) Use of pancreatic $\mathrm{B}$ cells in culture to identify diabetogenic $\mathrm{N}$-nitrosos compounds. In Vitro 19:25-30

3. Byrne PJ, Schein PS (1981) Streptozotocin. In: Prestayko AW, Baker LH, Crooke ST, Carter SK, Schein PS (eds) Nitrosoureas: current status and new developments. Academic, New York, pp 367-377

4. Wilson GL, Mossman BT, Craighead JE (1980) Diabetogenic effects of chlorozotocin on murine pancreatic beta cells in vitro and in vivo. J Cell Biol 87: $327 \mathrm{a}$

5. Rossini AA, Williams RM, Appel MC, Like AA (1978) Complete protection from low-dose streptozotocin-diabetes in mice. Nature $76: 182-183$

6. Rossini AA, Like AA, Dulin WE, Cahill GF (1977) Pancreatic beta cell toxicity by streptozotocin anomers. Diabetes $26: 1120-1124$
7. Ganda OP, Rossini AA, Like AA (1976) Studies on streptozotocin diabetes. Diabetes 25: 595-603

8. Anderson T, Schein PS, McMenamin MG, Cooney DA (1974) Streptozotocin diabetes. Correlation with extent of depression of pancreatic islet nicotinamide adenine dinucleotide. J Clin Invest 54: 672-677

9. Schein PS, Cooney DA, Vernon ML (1976) The use of nicotinamide to modify the toxicity of streptozotocin diabetes without loss of antitumour activity. Cancer Res 27:2324-2331

10. Ho CK, Hashim SA (1972) Pyridine nucleotide depletion in pancreatic islets associated with streptozotocin-induced diabetes. Diabetes 21: 789-793

11. Yamamoto H, Uchigata Y, Okamoto H (1981) Streptozotocin and alloxan induced DNA strand breaks and poly (ADP-ribose) synthetase in pancreatic islets. Nature 294: $284-286$

12. Uchigata Y, Yamamota H, Kawamura A, Okamoto H (1982) Protection by superoxide dismutase, catalase, and poly (ADP-ribose) synthetase inhibitors against alloxan-and streptozotocin-induced islet DNA strand breaks and against the inhibition of proinsulin synthesis. Biol Chem 257: 6024-6088

13. Uchigata Y, Yamamoto H, Nagia H, Okamoto H (1983) Effect of poly (ADP-ribose) synthetase inhibitor administration to rats before and after injection of alloxan and streptozotocin on islet proinsulin synthesis. Diabetes 32: 316-318

14. Wheeler GP (1975) In: Sartorelli AC, Johns DG (eds) Handbook of experimental pharmacology, Vol38, Springer, New York, pp 65-79

15. Wheeler GP (1975) In: Sartorelli AC (ed) Cancer chemotherapy, Vol 30. American Cancer Society, Washington DC, pp 87-119

16. Colvin M, Brundrett RB, Cowens W, Jardine I, Ludlum DB (1976) A chemical basis for the antitumour activity of chloroethylnitrosoureas. Biochem Pharmacol 25: 695-699

17. Reed DJ, May HE, Boose RB, Greagory KM, Beilstein MA (1975) 2-chloroethanol formation as evidence for a 2-chloroethyl alkylating intermediate during chemical degradation of 1-(2-chlorethyl)-3-cyclohexyl-1-nitrosourea and 1-(2-chlorethyl)-3-(trans4-methylcyclohexyl)-1-1nitrosourea. Cancer Res 35: 568-576

18. Ewig RAG, Kohn KW (1977) DNA damage and repair in mouse leukaemia LI2IO cells treated with nitrogen mustard; 1,3-bis(2-chloroethyl)-1-nitrosourea and other nitrosoureas. Cancer Res 37: 2114-2122

19. Ewig RAG, Kohn KW (1978) DNA protein crosslinking and DNA interstrand crosslinking by haloethyl nitrosoureas in LI2IO cells. Cancer Res 38: 3197-3203

20. LeDoux S, Wilson GL (1984) Effects of streptozotocin on a clonal isolate of rat insulinoma cells. Biochem Biophy Acta 804:387-392

21. Ireland CM, Eastman A, Bresnick E (1982) DNA-protein crosslinks induced in a hamster tracheal epithelial cell line by benzo (a) pyrene. Biochem Biophys Res Comm 109 (4): 1291-1296

22. Kohn KW, Erickson LC, Ewig RAG, Friedman CA (1976) Fractionation of DNA from mammalian cells by alkaline elution. Biochemistry 15: 4629-4637

23. Kohn KW (1979) DNA as target in cancer chemotherapy: Measurements of macromolecular DNA damage produced in mammalian cells by anti-cancer agents and carcinogens. In: DeVita VT, Busch H (eds) Methods in research. Vol 14. Academic, New York, pp 291-345

24. Gralla RJ, Tan CTC, Young CW (1979) Phase 1 trial of chlorozotocin. Cancer Treat Rep 63:17-20

25. Margison GP, Kleihues P (1975) Chemical carcinogenesis in the nervous system: Preferential accumulation of $\mathrm{O}^{6}$-methylguanine in rat brain deoxyribonucleic acid during repetitive administration of N-methyl-N-nitrosourea. Biochem J 148: 521-525

Received: 5 August 1985

and in revised form: 20 December 1985

Dr. Brooke T. Mossman

Department of Pathology

University of Vermont

College of Medicine

Burlington, VT 05405

USA 